College of William \& Mary Law School William \& Mary Law School Scholarship Repository

Faculty Publications

Faculty and Deans

1985

\title{
The Economic and Cultural Impact of the Origins of Property: 1180-1220
}

Robert C. Palmer

\section{Repository Citation}

Palmer, Robert C., "The Economic and Cultural Impact of the Origins of Property: 1180-1220" (1985). Faculty Publications. 902.

https://scholarship.law.wm.edu/facpubs/902

Copyright c 1985 by the authors. This article is brought to you by the William \& Mary Law School Scholarship Repository. https://scholarship.law.wm.edu/facpubs 


\title{
The Economic and Cultural Impact of the Origins of Property: 1180-1220
}

\begin{abstract}
Robert C. Palmer
The development of property in England between 1176 and 1220 was the result of a complicated interaction between social mores made law and bureaucratic action. In the Assize of Northampton, Henry II undertook regular supervision of proprietary decisions to prevent his men from preparing a rebellion like that of 1173-74. The supervision assumed peacetime feudal norms, but in the hands of bureaucratic justices even prior to 1200 this supervision increasingly restricted lords' power to discipline their tenants, at a time when disciplinary power was far more important than proprietary decisions. By 1220 , the relative importance of proprietary matters and disciplinary power had been reversed. But proprietary action by the lord was so attenuated that seisin-lawful possession-was possible now even without lordly acceptance. Such insulation of the tenant from his lord was a bond established between the tenant and his tenement: property. ${ }^{1}$ Similarly, insulation of tenant from lord constituted a relative increase in knightly independence: the obverse side of the centralization of power and interest embodied thereafter in the English Parliament.
\end{abstract}

Robert C. Palmer is the Adler Fellow of the Institute of Bill of Rights Law and Associate Professor of Law at the Marshall-Wythe School of Law, The College of William and Mary. Versions of this paper have been given, notably at the University of Chicago Law School, the New York University seminar in law and history, and the Sixth British Legal History Conference. The criticisms at these meetings have proved uniformly helpful. This article was written with the aid of a summer research grant from the National Endowment for the Humanities. I am indebted to Nicholas Mayhew and Peter Spufford for allowing me to use their work prior to publication, and to Dr. Paul Hyams for drawing my attention to their work. I would like to thank Kathleen Crotty, my research assistant at Marshall-Wythe.

1. The short forms for frequently cited works are the following:

Bolton, English Economy: J.L. Bolton, The Medieval English Economy, 1150-1500 (London, 1980).

Glanvill: The Treatise on the Laws and Customs of the Realm of England Commonly Called Glanvill, G.D.G. Hall, ed. (Oxford, 1965). The author will, as is customary, be referred to as 'Glanvill' for reasons of convenience.

Harvey, 'English Inflation': P.D.A. Harvey, 'The English Inflation of 1180-1220', in Peasants, Knights and Heretics, R.H. Hilton, ed. (Cambridge, 1976), 57-84.

Mayhew, 'Frappes de monnaies': Nicholas J. Mayhew, 'Frappes de monnaies et hausse des prix en Angleterre de 1180 à 1220', in John Day, ed., Etudes d' histoire monétaire (Lille, 1984).

Palmer, 'Origins of Property': Robert C. Palmer, 'The Origins of Property in Eugland', 3 Law and History Review 1-50 (1985).

Spufford, 'Le rôle de la monnaie': Peter Spufford, 'Le rôle de la monnaie dans la révolution commerciale du xiii' Siècle', in John Day, ed., Etudes d' histoire monetaire (Lille, 1984). 
The impact of the origins of property was immediate and substantial, both in economic terms and in the cultural perceptions of justice. Far more than any other factor, the appearance of property as a legal phenomenon was the cause of the inflation of 1180-1220. That inflation was the first of the two great pre-modern inflations. It constitutes an economic gauge of the social importance of the beginnings of the common law. Moreover, the development of the law produced a change in the way people regarded authority, thus altering their perceptions about the nature of justice. Customs, when transformed into the common law, lost their flexibility and produced anomalous decisions that were nevertheless considered just. The magnitude of both the economic and cultural changes demonstrates the importance of the change in security of tenures which otherwise might now have been dismissed as an incremental change little different in kind from previous or subsequent alterations in the law.

That law should have such an impact is in itself not surprising. Admittedly, only a few people were involved in litigation on any given point, so that direct participation in litigation was not the main avenue whereby the law affected society. The use of standardized writs that could and did carry predictable consequences, the use of sworn panels of people from the neighborhood to render verdicts, the use of eyres spread familiarity with the law rapidly among the baronage and the knightly tenants, particularly at the beginnings of the bureaucratic law when it was not significantly different in terminology and substance from social mores. The law operating in nearly familiar forms, focused tightly on particularly vital points of important social relationships, thus constituted a substantial social-economic force; it was institutionalized royal authority. That force impacted on those determined to pursue traditional courses and on those ignorant of new ways. In some areas, it produced new and sometimes more effective ways to accomplish traditional objectives. Nevertheless, more effective instruments dictated that many were deterred from acting in other ways that were now subject to legal redress. Each facility entailed a restriction.

\section{The Great Inflation}

England experienced a major inflation between around 1180 and 1220 . During that forty year period prices increased something like $300 \% .^{2}$ Prices increased for grains, livestock, military pay, and probably also for skilled work and agricultural services generally. ${ }^{3}$ Moreover, no sector of the

2. Harvey mentions once that prices doubled or trebled in the forty years (Harvey, 'English Inflation', 58), but several times about three-fold rises in prices (ibid., at 67, 69,80 ). Bolton does not hazard an estimate at the total inflation involved, but characterizes it as 'rapid' (Bolton, English Economy, 21-22, 73, 76, 87). Both Mayhew and Spufford follow Harvey's estimate of the degree of the inflation. Mayhew, 'Frappes de monaies', 160; Spufford, 'Le rôle de la monnaie', 365-66.

3. Harvey, 'English Inflation', 58, 67, 69, 71. Bolton provides some figures for wheat 
populace seems to have been particularly damaged. ${ }^{4}$ The towns, which would have been particularly susceptible to injury from any increase merely in agricultural prices, prospered nonetheless. ${ }^{5}$

The effects of the inflation were manifold. Economic historians attribute to the inflation the change in agricultural management from farmers (longterm lessees) to the use of bailiffs: a rational and successful effort to capture real value embodied in produce instead of a deteriorating fixed return. ${ }^{6}$ P.D.A. Harvey, in a very influential article, attributed various other things to the inflation: the termination of commutation of traditional labor services into money rents, the decline of villein status and the exclusion of villeins from common law protection, the decline in the standing of the Jews (whose wealth was all in money of declining value), the difficulties of King John (who was more adversely affected in his income than were other lords), and the rebellion that produced Magna $\mathrm{Carta}^{7}$ For Harvey, and only to a somewhat lesser extent for other economic historians, ${ }^{8}$ the inflation was a major determinant of the condition of life in thirteenth-century England. In that society, a trebling of prices over the relatively short period of forty years could not help but have a dramatic impact on society, whether or not in the ways Harvey argued.

Having traced the effects of the inflation, however, economic historians have had less success in proving causation. Harvey has stated that while the phenomenon of a drastic rise in prices was generally accepted, its nature as a monetary inflation (thus affecting all prices and not just selected sectors) was less certain, and that the causes were speculative. ${ }^{9}$ Harvey, J.L. Bolton and Nicholas Mayhew, however, all rule out coinage manipulation for the 1180-1220 inflation: while changes in the metal content of the coinage had

(more than doubled over the period: Bolton, English Economy, 69), but characterizes the general price increase in grains and livestock only as 'rapid': ibid. at 72 . The precise degree of inflation is not important. Given the legal changes, even the absence of an inflation would be significant as indicating radical deflationary pressures.

4. D.A. Carpenter, 'Was There a Crisis of the Knightly Class in the Thirteenth Century?', English Historical Review 95 (1980), 744-48, in response to P.R. Coss, 'Sir Geoffrey de Langley and the Crisis of the Knightly Class in Thirteenth-Century England', Past and Present, 68 (1975), 26-28. For villeins, see generally Hyams, King, Lords, and Peasants in Medieval England (Oxford, 1980), 221-65.

5. Harvey, 'English Inflation', 71; Susan Reynolds, An Introduction to the History of English Medieval Towns, corrected reprint (Oxford, 1982), 46-51.

6. Harvey, 'English Inflation', 58-59; Bolton English Economy, 87-88. Bolton mentions the interesting phenomenon that lay estates seemed to lead the way in the introduction of bailiffs.

7. Harvey, 'English Inflation', 67, 73-79, summarized also in Bolton, English Er'onomy, 76.

8. Bolton, English Economy, 73 ('the rapid inflation of 1180-1220 which set off the thirteenth-century boom'); Mayhew, 'Frappes de monnaies', 172-74.

9. Harvey, 'English Inflation', 79. 
some effect later on, there was no significant alteration at this time. ${ }^{10}$ The inflation was thus not illusory: goods actually cost more in terms of precious metal and not merely in terms of number of coins.

Harvey believes that phenomenal economic growth may have been responsible. He thinks that the strengthened government, after the Anarchy, permitted explosive growth in the export of various commodities to Europe: primarily of wool, but also of finished cloth, tin, and grains. The magnitude of these exports was such that it was not balanced by imports, so that payment for English goods was primarily in silver. ${ }^{11}$ The dramatically increased volume of silver in England made every silver coin-the silver content of each remaining stable-worth less in terms of purchasing power. The price of all goods and services thus rose, producing a monetary inflation: an inflation affecting all goods and services.

Nicholas Mayhew, more recently, has shown that there was a substantial influx of silver during these years. ${ }^{12}$ The quantitative scale of that influx, however, remains open to question; and the slowing of the inflation around 1220 to a relatively mild inflation during the next forty years, when one might have expected continued inflation based on silver coinage statistics, argues against a mono-causal monetarist explanation. ${ }^{13} \mathrm{~J}$.L. Bolton, writing well before Mayhew, prefers a demographic explanation for the price rise: increasing population and increased farming of marginal land put greater demand on limited resources so that prices rose. ${ }^{14}$ As Mayhew has remarked, population growth tends to proceed relatively more slowly, so that demographics has a hard time explaining such a sudden and dramatic inflation. ${ }^{15}$ Nonetheless, demographers will probably not acquiesce totally to Mayhew's figures, which are approximations, ${ }^{16}$ or to an explanation based solely on monetarist theory. ${ }^{17}$

10. Ibid. at 80; Bolton, English Economy, 75-77; Mayhew, 'Frappes de monnaies', 167-68.

11. Harvey, 'English Inflation', 81-82.

12. Mayhew, 'Frappes de monnaies', 160-68. The quantity of silver involved is far from certain. Mayhew's figures show a definite increase. The quantity involved is rendered uncertain by his necessary reliance on estimated figures for the percentage of total production of the various coins based in two small provincial mints (Carlisle and Lincoln). An important factor in the estimate (necessary for purposes of comparison to other statistics) is that each die produced 20,000 coins. The proper estimate of production from each die, as he explains at the beginning of his piece, is from 15,000 to 20,000 . Ibid., at 63 . For the purpose of calculating actual increase in silver, therefore, the figures must be reduced, possibly by $20 \%$.

13. Harvey, 'English Inflation', 58; see the coinage figures in Mayhew, 'Frappes de monnaies', 165.

14. Bolton, English Economy, 73-78.

15. Mayhew, 'Frappes de monnaies', 167.

16. Ibid. at 165-67.

17. The polarization between the monetarists and the demographers is well-known. See Mavis Mate, 'High Prices in Early Fourteenth Century England: Causes and Con- 
Harvey seems to have the stronger case for the causation of the inflation; wool production does indeed seem to have increased under the Angevins. ${ }^{18}$ Still, there is no way to gauge the actual degree of exporting: there are no export or import schedules. Moreover, the gold:silver ratio is inconclusive. It changed, between 1159 and 1186, from 1:10 to 1:12; a devaluation of silver that would be consistent with an increase in the amount of silver in England. But for the vital time between 1186 and 1220 there is no similar evidence of change: the gold:silver ratio in 1265 was still $1: 12 .{ }^{19}$ Harvey reserved the possibility of intermediate fluctuations, but the continuity lends little support to the numismatic evidence. ${ }^{20}$ Harvey's theory of causation for the inflation is thus not completely hypothetical, but it remains to be demonstrated that the quantity of silver coming into England could cause the degree of inflation that actually occurred and that the increase in silver actually was the mainspring behind the inflation.

Bolton is skeptical about the monetarist theory of causation. Much of his skepticism comes from the lack of observable phenomena after 1220 that would confirm Harvey's scenario. ${ }^{21}$ Bolton supports his view with the example of a single manor in which wages did not rise between 1201-1210 and 1281-1290..$^{22}$ The importance of such single items of information is indicative of the lack of information and the hypothetical nature of economic history of that time. Bolton's major concern with Harvey's suggested causation, however, is based on what he sees as its improbability. He thinks it improbable that the English failed to import much from the Continent, since the Germans seemed to think England a good market at this time. Importation of goods, of course, would mean a less favorable balance of payments and less importation of silver. Likewise, he notes that no one

sequences', Economic History Review second series, 28 (1975), 6-8; N.J. Mayhew, 'Numismatic Evidence and Falling Prices in the Fourteenth Century', Economic History Review, second series, 27, (1974), 1-2.

18. T.H. Lloyd, The English Wool Trade in the Middle Ages (Cambridge, 1977), 6-9. He emphasizes that it was in part a resumption of the wool trade interrupted by the Anarchy. His account suggests that the Flemings were very much involved in the trade, so that Bolton's caveats about the recipients of the major profits may be well founded. Infra note 23. Likewise, although there was a rough correspondence between a temporary slowing in the inflation in the early 1190 s, antagonism toward the Flemings, and interruption of the wool trade, the primary cause of the slowing of the inflation was the collection of Richard's ransom. Payment of the ransom would normally have resulted in massive deflation; the lack of substantial deflation indicates substantial inflationary pressures at work.

19. Harvey, 'English Inflation', 80-81. Mayhew does not address the gold:silver ratio.

20. Mayhew, 'Frappes de monnaies', 160-65.

21. Bolton, English Economy, 76.

22. Ibid. at 77. The evidence is that on the Winchester manors the piece rates for winnowing grain 'were virtually the same in 1281-90 as they had been in 1201-10'. This may well indicate nothing, as Bolton admits. (See his table of comparative rates between manors for the high degree of variation possible. Ibid. at 71.) Or it may indicate that increased liquidity of resources might not be exactly equivalent to an increase in specie in relation to certain kinds of activities subject to modest control. 
knows who was controlling the wool exportation: it could have been in the hands of aliens and thus the profits could have been directed out of England. Finally, the Angevins are well-known for the massive amounts of silver exported from England providing for their wars in Europe, the Third Crusade, and the ransom of Richard I. Such deflationary exports of currency would necessitate even more massive exportation still to have resulted in the inflation: he finds the odds against such a massive and unbalanced exportation of goods unbelievable. ${ }^{23}$ Harvey prefers the demographic model, only because it seems more believable, not because he can prove it. Still, he advances no convincing explanation for why there was the dramatic inflation over the forty years, 1180-1220, and not more moderate inflation over a longer period of time: the latter a pattern perhaps more believable as the consequence of demographic pressures. In short, the economic historians who have dealt seriously with the inflation all have serious problems in determining its causes.

For present purposes, the most striking aspect of the inflation is that it was insular: there was no substantial Continental parallel. ${ }^{24}$ Thus the change in agricultural management from farmers (long-term lessees) to bailiffs who accounted for all the proceeds was solely an English phenomenon. ${ }^{25}$ This insularity seems to undermine demographic change as the cause of the inflation, for the demographic changes had clear Continental parallels. ${ }^{26}$ Given the similarity between Continental and English demographics, it would be hard to explain the English character of the inflation if the inflation had been fueled by the increase in population.

Harvey perceived that the insularity of the inflation might indicate some causative relationship with another insular phenomenon: the growth of the common law. Both happened between roughly 1180 and 1220; neither had Continental parallels; both had a direct relationship to economic resources. ${ }^{27}$

23. Ibid. at 77.

24. Harvey, 'English Inflation', 61. Bolton does not comment on the comparative question. Mayhew suggests a Continental parallel, but admits that the margin of error is very wide; moreover, the probability is that elsewhere inflation was much less drastic and peaked somewhat later. Mayhew, 'Frappes de monnaies', 167-72. Spufford emphasizes the severe nature of the English inflation evidenced by the change in English agricultural management from longterm leases to bailiffs and emphasis on labor services instead of money rents, whereas Continental agriculture reacted to a much milder inflation by changing labor services to money rents. Spufford, 'Le rôle de monnaie', 365-66.

25. See supra note 24 .

26. Robert S. Lopez, The Commercial Revolution of the Middle Ages, $950-1350$ (Englewood Cliffs, 1971), 27-30.

27. One of the more perplexing aspects of economic historians' reluctance to treat law as a possible source of economic and social change is that they are perfectly ready to treat law as an instrument of oppression. See Harvey, 'English Inflation',77; R.H. Hilton, 'Freedom and Villeinage in England', in Peasants, Knights and Heretics, supra note 1 at 184-190. Perhaps the explanation is the supposition that law as an instrument of oppression expresses accurately and without distortion the desires of its makers. 
Mere coincidence, of course, is always a possibility; in this case there was a causal relationship. Harvey, however, mistakenly maintained that the inflation caused the law. In that scenario, an inflation of hypothetical origin put lords in such economic straits that they resisted further royal exactionsthus freezing feudal custom into law for themselves-but resisted any royal interference in the exercise of their control over the majority of their peasants-thus freezing villeins out of common law protection. ${ }^{28}$ The single strength of the suggestion is that it accounts for two gross legal phenomena: the feudal content of English law and the exclusion of villeins. The weaknesses, however, are overwhelming. His scenario does not account for the complexities of the law or for legal forms. Nor does it account for the fact that, while the law did not protect everyone, it nonetheless served many insignificant peasants, whom the law classified as free tenants capable of using the assize of novel disseisin. French law was not so generous. Moreover, his scenario portrays law as the final link in the chain of causation: a mere reflection of social change. Law, however, is a bureaucratic and economic force directed (intentionally or not) at highly focused points of social organization: the law has both social and economic impact. $^{29}$

My thesis is that the increased insulation of tenants from lordly control was equivalent to an increase in the ability to manipulate land as an economic resource. That phenomenon, the result of many incremental political and bureaucratic events over the forty years, ${ }^{30}$ necessarily resulted in great inflationary pressure, particularly since land was still the major form of economic resources around 1200 . The economic theory on which the thesis rests can be stated in two different ways. A simple supply and demand formula is the more comprehensible. When a (here, the) major economic resource of a community becomes more available to fund purchases, prices of all items will increase, provided that the supply of items does not increase as fast as demand and purchasing power. The only brake on such a price increase would be the lack of a medium of exchange to convert the economic resource into actual funds, assuming the superior efficiency of coinage over barter. No such brake would operate at this time in England. ${ }^{31}$ As land, then, became more usable as an economic resource, that is, as that economic resource became more liquid, inflation was inevitable. The same

28. Ibid. at 73-78; for a better evaluation, see generally Hyams, Kings, Lords, and Peasants, supra note 4 at 221-65.

29. R.C. Palmer, The Whilton Dispute, 1264-1380: A Social-Legal Study of Dispute Settlement in Medieval England, (Princeton, 1984), 15-17.

30. Palmer, 'The Origins of Property', 1-47.

31. Mayhew, 'Frappes de monnaies', 160-72; Spufford, 'Le rôle de la monnaie', 357-60. The economic situation of England was determined by the coincidence of the two major sources, interacting but with separate origins: the greater control by tenants of the land as an economic resource (resulting from the common law and political decisions) and the availability of silver to facilitate the easy use of the land as an economic resource (resulting from the new German silver mines and passing through England via, among other things, the wool trade). 
result, but less intelligibly, derives from the disputed Fisher equation: $\mathrm{PT}=\mathrm{MV} \cdot{ }^{32}$ Here $\mathrm{P}$ is the general price level; $\mathrm{T}$, the number of transactions; $\mathrm{M}$, the money supply; $\mathrm{V}$, the velocity of money circulation. P obviously increased markedly: that was the content of the inflation. One can assume that $\mathrm{T}$ increased to some extent, because England had a reputation for consumption at this time. ${ }^{33} \mathrm{M}$ increased noticeably. ${ }^{34}$ And finally, $\mathrm{V}$ (which has long been unknown for this time ${ }^{35}$ ) increased substantially with the increased liquidity of land as an economic resource (assuming again that people did not refrain from spending). Before proceeding, it should be noted that no one knows, or for present purposes needs to know, the absolute level of the use of land as a liquid economic resource, provided the absolute level was not miniscule. The relative increase is the significant factor. Any increase in the actual liquidity of such a major economic resource would have an immense impact on prices.

Precisely those changes in the common law already described, albeit perceived in a different context, explain the great inflation of 1180-1220. Two gross changes are significant. The first is the increase in alienability ${ }^{36}$ by tenants. Full alienability is, of course, in some sense the final implication of liquidity. For medieval England it was an important, but not the most significant factor. ${ }^{37}$ More important than full alienability was the increased ability of tenants to use land as security for loans. Together, these two alterations constituted a major change in the liquidity of land as an economic resource, a change of such dimensions that it fueled an inflation of nearly $300 \%$ over the course of forty years despite severe deflationary pressures.

Glanvill indicated around 1188 that alienation was difficult. He did not even mention the problems inherent in substitution: ${ }^{38}$ a substitution without the lord's consent was still unthinkable, because the tenant's title was still a

32. Bolton, English Economy, 73. See the cautions on the Fisher equation in Mate, 'High Prices', supra note 17 at 6-8.

33. Harvey, 'English Inflation', 68.

34. Mayhew, 'Frappes de monnaies', 160-65.

35. Bolton and Mayhew assert that little can be known concerning $V$ for the late twelfth and early thirteenth centuries. Bolton, English Economy, 73-74; Mayhew, 'Frappes de monnaies', 174). That may be true in general, but not in this particular instance.

36. The increase in alienability is not a matter of dispute, but has been a matter of consensus among legal historians since Maitland. F. Pollock and F. W. Maitland, The History of English Law Before the Time of Edward I, 2nd. ed. with introduction by S.F.C. Milsom (Cambridge, 1968), 1:329-37. The only issue is whether the change occurred intentionally or by juristic accident. R.C. Palmer, 'Feudal Framework of English Law', 79 Michigan Law Review 1132 (1981).

37. Alienation might have been quite significant, in that a tenant might well have been willing to sell a small portion of a tenement or the whole of a tenement held of other than his main lord. Usually, however, tenants tended to want to retain the fee and resist complete alienation. In such a society, less drastic options for tenants assume greater importance.

38. Pollock and Maitland, History of English Law, supra note 36 at 1:332n; S.F.C. Milsom, The Legal Framework of English Feudalism (Cambridge, 1976), 103-104. 
personal relationship. The difficulties encountered even in subinfeudation, however, were immense. Both lord and tenant's (eventual) heir shared with the current tenant the power of granting the land. The lord's interest was rather less than the eventual heir's, but no less restrictive. No tenant could subinfeudate in such a way that the services would be endangered: that would be cause for immediate disciplinary disinheritance. ${ }^{39}$ Thus, even though a tenant could grant anyone a reasonable portion of his land (to be held thus of the grantor ${ }^{40}$ ) the reasonableness of the grant was a matter for determination by the lord and his court. The possible sanction-the loss of the whole fee held of that lord-was sufficiently severe that only desperation would push a tenant into a grant that would seem excessive to the lord.

The heir's right was less predictable. His ability to nullify his deceased father's grant derived from the original character of feudal grants-grants in fee-as personal relationships, so that the grant ended with the death of either party. Thus, originally, homage had to be done at the death of either lord or tenant. ${ }^{41}$ Prior to 1176 , then, an heir, on succeeding to the lordship of his father, was bound to renew grants only to the extent that moral/ political considerations bound him. Those considerations should not be underestimated, because they formed the basis for the lordly heir's authority and the exercise of his influence. But after the provision of mort d'ancestor and novel disseisin, not even the death of both parties rendered a homage ineffective: the tenant's heir had an enforceable right to enter the tenement. The lordly heir's power to revoke his father's grant, however, survived in the context of grants by fathers to younger sons. Such a grant was intrinsically unreasonable: ${ }^{42}$ the first-born would inevitably revoke the grant with no adverse consequences. A grant to daughters, however, was far more stable: $^{43}$ no sane person would have granted excessively to a daughter, whereas fathers notoriously favored younger sons. ${ }^{44}$ Such a suspect grant to a younger son, then, could only be made stable if the first-born made the grant his own: by confirmation at the time of the father's grant. ${ }^{45}$ Problems,

39. Glanvill, IX.1.

40. Ibid. at VII.i.

41. Thorne provides a chronology that (1) prior to 1166 homage had to be renewed at the death of either party, (2) after 1166 homage did not have to be renewed as long as either party survived, and (3) after 1176 the homage bar subsisted even to benefit the tenant's heir. The date of 1166 depended, apparently, on the supposition that the assize of novel disseisin became a general remedy at that time. It is thus better to use 1176 as a major changing point until it is clear how novel disseisin really developed. S.E. Thorne, 'English Feudalism and Estates in Land', 17 Cambridge Law Journal 200-201 (1959).

42. Glanvill, VII.1. This statement applies only to the inherited land. The sociological explanation for the greater acceptance of grants from acquired lands (in feudal relations) is that lords preferred such arrangements: it tended to reduce the number of tenants with multiple lords.:

43. Ibid.

44. Ibid. See Palmer, Whilton Dispute, supra note 29 at 28-60.

45. Glanvill, VII.1. By Glanvill's time, the necessity for the heir's consent to ordinary 
however, might arise even in such a grant and confirmation. Unless the confirmation by the apparent heir worked as some variety of conveyancing magic - a highly improbable suggestion for the twelfth-century contextthen the grant would still fail if the apparent heir predeceased his father, leaving as the real heir the second son who had not approved the father's grant to the third son. The personality of grants cannot be ignored; nor can the real limitations imposed by death in a society in which no bureaucratic agency existed to grant one an afterlife of decision-making and control. Moreover, even the obligation of warranty in regard to ordinary grants was conditional. Glanvill's phraseology must be carefully observed: the heir had to warrant all his ancestor's reasonable grants. ${ }^{46}$ Unreasonable grantsgrants that endangered the integrity of the fee-could still be avoided.

The effect of the legal changes in the years from Glanvill to 1220 was the consolidation of the power to alienate by subinfeudation into the hands of the current tenant in fee. The lord had had the authority to disinherit a tenant who by imprudent grants from the tenement had endangered the services due. In the 1190 s and the early thirteenth century such disinheritances became very difficult. They could be accomplished, if at all, only by legal proceedings in the king's court pursuant to a writ of right. A straightforward disinheritance in the lord's court for proper disciplinary motives fell under the censure of the assize of novel disseisin. ${ }^{47}$

Like the lord's power to disinherit for disciplinary reasons, the heir's power to revoke his ancestor's unreasonable grants disappeared: that disappearance was a complex but integral aspect of heritability and warranty. Mort d'ancestor dictated that the heir of a seised tenant could occupy the land, regardless of whether the lord or the lord's heir approved. ${ }^{48}$ The writ of right dictated that the acceptance of a tenant by an entitled lord would constitute an obligation for the current lord, subject to the discretionary considerations of the grand assize. ${ }^{49}$ The obligation to warrant not only

grants to strangers had been superseded by the emphasis on warranty, leaving only certain categories of suspect grants particularly requiring the heir's consent: grants to younger sons, death-bed grants, and perhaps a few others. Otherwise, the heir's opposition was ineffective.

46. Ibid. at VII.2.

47. Palmer, 'Origins of Property', 21-24.

48. The Assize of Northampton identified the lord as the primary person responsible for keeping an heir out of the tenement, so that his approval was not presumed. Palmer, 'Origins of Property', 13-17; S.F.C. Milsom, Historical Foundations of the Common Land, 2nd. ed. (London, 1981), 134-37.

49. Palmer, 'Origins of Property', 8-11, 24. The grand assize asked the sworn panel who had greater right. The comparative nature of that issue meant that the panel, if so disposed, could consider all those discretionary values that lords and their courts had properly considered, although now less effectively because transposed from their natural setting. Thus transposed, those discretionary considerations seem largely to have died out in favor of strict rules of law, only partly because the grand assize declined in use. 
personal but also ancestral grants-providing escambium if necessary in cases of double obligation-showed the determination of the king's court not to allow a homage to perish $;^{50}$ the lord and heir rule showed the same determination. ${ }^{51}$ The preservation of homages was the bureaucratic manifestation of the purposes of the Assize of Northampton. ${ }^{52}$ As long as such obligations finally ended in the grand assize, warranty obligations could remain flexible and reasonable. But with ostensibly three-handed writs of entry the issue would come before a jury, not a grand assize. That jury would determine a narrow issue of fact. Thus, if there had been an acceptance, the lord would be bound. ${ }^{53}$ The rigidity that assured inheritance by a tenant's heir was thus, from a different perspective, the (lord's) heir being unable to revoke his father's unreasonable grant. The lord's heir was bound, to the complete extent of his inheritance from his predecessor, the grantor. ${ }^{54}$ The rules that applied between the lord and his heir applied also as between tenant and tenant's heir, because tenant could in turn be lord to further tenants. Consolidation of control over subinfeudation into the hands of the current tenant was thus not an abstract preference in favor of free alienability of the fee, ${ }^{55}$ but a necessary by-product of the suppression of disciplinary disinheritance and the honoring of established homage relationships.

Between 1176 and 1220, then, the control and interests over any particular free-holding of land became concentrated, gradually and increasingly, in the current tenant. The heir was left with no control, but with a secure inheritance in whatever fee had remained with his father at death. The lord was left with a secure interest in the feudal incidents, but with no disciplinary power. The concentration of rights allowed the current tenant to sell securely and without the participation of anyone but the tenant himself and the purchaser, who would have to hold the land from the grantor, the previous tenant. Moreover, the sale would be secure-if performed correctly - and would last in perpetuity, not just for the lives of the original parties. Land had been changed from a relatively frozen asset to a relatively liquid asset. Regardless of the absolute level of transactions, land could now enter the market in a decisive way.

The process, nonetheless, was not one clearly recognized by the people who lived through it. There was not a grand moment at which the court

50. Glanvill, III.1. The language about a homage perishing comes from Glanvill and indicates the almost surreal quality that homage had taken on. Ibid. at VII.12.

51. The lord and heir rule mandated that relatives play musical chairs with the tenement to prevent the lordship and tenancy from collapsing, regardless of whether the results were at odds with the intent of the donor. Once a homage had been established, it was not allowed to perish unless for complete lack of possible heir.

52. Palmer, 'Origins of Property', 12-23.

53. Henry de Bracton, De Legibus et Consuetudinibus Angliae, G.E. Woodbine, ed. and S.E. Thorne, trans. (Cambridge, Mass. and London, 1968), 4:196, 215, 235.

54. Milsom, Historical Foundations, supra note 48 at 179.

55. Palmer, 'Feudal Framework', supra note 36 at 1133-34. 
announced to the populace-or even to lawyers - that the fee was alienable and outlined the rights of tenants. The persistence of the grand assize precluded that. ${ }^{56}$ But right around 1200 it is clear that prospective heirs no longer had to consent. Perhaps even more telling, simultaneously grants came to be made not just to 'A and his heirs' but also to 'A and his heirs and assigns', thus acknowledging the ability of a grantee to alienate. ${ }^{57}$ Even so, perception lagged behind court practice. Seemingly, also, other valuesmoral and traditional-slowed the utilization of the new possibilities. Even in the mid-thirteenth century the absolute frequency of sales was not high. ${ }^{58}$ But unless restraint was indeed phenomenal, there had been a significant increase spread over the forty years. The slowly increased utilization of the incremental alterations in the manipulability of the major form of wealth would account for at least part of the force behind the inflation between 1180 and 1220 .

The second change-the greater ease in using land as security for loans-was the more economically significant development. By 1220 tenants could certainly use land as security for loans. Granting a term in the land, even if not strictly as a gage, was an easy method of obtaining a loan. Later in the thirteenth century the courts made it possible for lenders to be assured of obtaining the proceeds of lands upon default, even though the creditors had not been previously in possession. That process proceeded by recognition and enrollment, but was not available before the late thirteenth century. ${ }^{59}$ Its importance here is that that process followed on from the substantial change in the early thirteenth century, establishing the direction in which the law concerning land and loans was developing. But the thirteenth-century part of the argument needs little proof. The frequency of the writ ad terminum qui preteriit argues strongly enough on its own for the frequency of the grant of terms. ${ }^{60}$ The use of land as security for loans might

56. Text supra at note 53 . Use of the grand assize had certainly declined between 1200 and 1220 , but the grand assize was hardly an infrequent phenomenon still in 1220 , because the writs of entry had not by that time taken hold of a large body of litigation: they were still used in only a few situations and then not very frequently.

57. Carpenter, 'Was There a Crisis', supra note 4 at 728.

58. Pollock and Maitland, The History of English Law, supra note 36 at 2:14, note 2: 'Generally in a collection of charters we shall find two changes occurring almost simultaneously soon after the year 1200:-(1) the donor's expectant heirs no longer join in the gift; (2) the donee's "assigns"' begin to be mentioned.' Bailey found a few mentions of assigns in grants prior to 1200 , in 1196 and 1199, but concluded that 'There is no indication yet [in the reign of Richard I], however, that the bond of warranty can ordinarily extend further to mere assigns'. S.J. Bailey, 'Warranties of Land in the Reign of Richard I', 9 Cambridge Law Journal 197-98 (1945).

59. T.F.T. Plucknett, Legislation of Edward I (Oxford, 1962), 136-61.

60. Ad terminum qui preteriit was not only the earliest, but also the most frequently used writ of entry. Early in the thirteenth century, the writ changed from mentioning a gage to mentioning a term. The difference is substantial, because that enabled the writ to protect a life tenancy also and not merely commercial arrangements. The motivation behind the change, however, is not clear, unless it was explicitly to make the writ more versatile. One would like to find a better reason. 
even be considered as strictly included in the broader capability to alienate without interference from lord or heir.

The frequency of gaging land in the twelfth century was low in relation to the same activity in the thirteenth century. The increasing facility to use land to secure loans in the thirteenth century argues in that direction: it makes one at least suspect that it was more difficult to use land in that way in the twelfth century. One early stage in the process may have been royal pressure to allow tenants to borrow to go on Crusade; another would have been the increase in coinage in Angevin England. ${ }^{61}$ The most convincing evidence, however, is the writ of entry ad terminum qui preteriit. That writ was two-handed, in that its reach was limited to the second tenant after the land had passed out of the claimant's line of title. Such two-handed writs always evidenced the loss of lordly control, because writs of entry were typically three-handed. Two-handed writs eliminated the lord from the writ, because it was a situation in which the lord had lost control and thus had done nothing in the transferal of the land. ${ }^{62}$ The writ of entry ad terminum qui preteriit originated at least as early as 1199 and already at that date can be found at full reach. Some years prior to 1199 , then, lords had exercised decisive control over gaging activities; by 1199 they had found that they could not effectively control gages. ${ }^{63}$

Twelfth century feudal control over gages complicated and retarded the use of land as an economic resource. Certain kinds of gages, of course, would be easy enough. If the lord was to be the creditor, there would be no problem. If the land involved was only a small portion of the whole tenement that would not endanger the services, a tenant had no reason to fear disciplinary disinheritance because of an excessive subtenancy. But if the land constituted either the whole tenement or a large enough portion to endanger the services (whether of one's whole tenement or of the tenement held of a particular lord), special care would be necessary. The tenant had to secure his lord's consent to the transaction. Any creditor would insist on that, and some might also insist on the heir's consent, particularly in cases when, on default, the land was to be held from the debtor. The lord would often have no interest in the arrangement as such, but would have great interest in making sure the creditor would be a suitable tenant. The younger son of another tenant, financed perhaps by his father, would be an attractive creditor; a money-lender might not.

Prior to 1176 , the multiple consents required from people with diverse standards and concerns retarded the use of land as an economic asset. Concentration of control over the land facilitated that use. By 1220 land had become about as liquid as it would be until the end of the fourteenth

61. Ralph de Diceto, Ymagines Historiarum in The Historical Works of Master Ralph de Diceto, William Stubbs, ed., Rolls Series, vol. 68b (London, 1884), 74.

62. Palmer, 'Origins of Property', 25-39.

63. Ibid. at 37-39. 
century. ${ }^{64}$ The late thirteenth century devices were desirable for creditors, but could not have had the same economic impact: the same degree of change was no longer possible. The facility for using land as security for loans, however, is precisely the kind of activity that would increase the velocity of the currency in existence or, from a different perspective, increase the economic resources available to purchase the existing stock of goods. Governmental action, directed at other and narrower ends, ${ }^{65}$ here had a social and economic impact of monumental proportions.

The precise economic effects of the legal changes are incapable of definition at this point, but some possibilities should be mentioned. One should not think solely of legal causation throughout the forty years. The concentration of control over tenements was the mainspring, but a complex interaction between legal doctrine and social change undoubtedly ensued. One activity made possible by the greater facility to borrow would be improvement of holdings, by the purchase or decreased slaughter of stock, by the addition of lands, by the use of better agricultural tools and routines. ${ }^{66}$ England's wool production expanded at this time, but one can posit a less explosive growth: the hypothesis of massive exports unbalanced by imports is unnecessary. ${ }^{67}$ Similarly, the inflation itself probably dictated that agricultural management change to bailiffs instead of long-term lessees.

The economic climate of the thirteenth century can thus be reconciled with the inflation. Tenants did not feel in dire economic straits. The greater liquidity of economic assets affected everyone who held land; those who were less fortunate peasants were the producers of high-priced foodstuffs. The inflation would have injured relatively few, and mostly only those whom historians cannot examine for lack of records. The use of bailiffs was an adjustment, not a response to excruciating economic pressure at all. Moreover, that change might have resulted from a shift in attitudes toward tenements. A tenant could be confident of his relationship with his lord, although knowing that everything depended on the personal relationship. In that situation, attention was diverted away from efficient management of the tenement and toward cultivation of the relationship. Moreover, there was always the insecurity of the possibility of disinheritance, particularly acute for those who held land from more than one lord. It was quite a different

64. The beginnnings of the use ('use' here defined not only as one party holding for the benefit of another, but also holding in such a way that there is a divergence between co-existing legal title and moral entitlement: Palmer, Whilton Dispute, supra note 29 at pp. $200-208,278$ ) enabled tenants to treat their land like chattels, avoiding various burdens and facilitating the payments of debts even after the tenant's death. It is unlikely that that greater facility had such an enormous impact, however, because the relative increase in liquidity would not have been as great as that between 1180 and 1220.

65. Milsom, Legal Framework, supra note 38 at 183-86.

66. Bolton, English Economy, 82-84, 88-90. Investment in this way, of course, produces deflation in the shortrun, although it would contribute to exports within a relatively short time. The investment cycle emphasizes the inflationary pressure.

67. See text supra at notes $18-20$. 
thing to be the owner of property. The concentration of control would result in a different attitude toward land: while lords remained important, the security of tenure would encourage the development of the tenant's economic, as distinct from relational base. ${ }^{68}$ In a similar vein, silver probably did flow into England, partly as payment for exports, partly for other reasons. The common law created a situation more favorable to lending than that in France; it would not be surprising had there been some influx of silver lured by the better opportunities in England. But one can also suppose that it flowed out of England, without losing the only explanation for the inflation. The precise nature of the interaction between the legal changes and the social-economic consequences-which perhaps in their turn made further legal alterations acceptable-was undoubtedly complex. The only sure thing is that the economics of the inflation were similarly complex, that the inflation cannot be explained in a mono-causal manner. Both $\mathrm{M}$ and $\mathrm{V}$ rose rapidly, and the rise in $\mathrm{V}$ related to the common law was not caused solely or even mainly by $M$, although $M$ and $V$ interacted. The rise in $P$, high as it was, was moderated necessarily by a rise in $T$, the number of transactions. This explanation is simply more believable than a purely monetarist argument. The common law was thus not the product of choices dictated by external financial pressures. It was the product of political problem-solving and bureaucratic judicial action, itself an economic phenomenon and force.

The political decisions and the bureaucratic actions of the justices, technical as the process was, were of great social moment. The common law did not originate in transfers of jurisdiction from feudal courts to the king's court. Indeed, the process was hardly a transfer in any significant sense. More than anything else, it was regulation. ${ }^{69}$ That regulation of feudal courts-intended at every point not to change feudal relationships as much as to make them operate by their own proper standards-eliminated lordly discretion, created property right, and thus severed the severe dependency of tenants on their lords. The magnitude of the change is evident from the magnitude of the inflation that resulted in part from the tenant's increased security and control over his tenement. An inflation of 300\% in forty years constitutes one of the two great pre-modern inflations. Fortunately for those in the thirteenth century, the inflation was part of a complex economic situation that created few victims. Thirteenth-century England knew growth and prosperity, not economic stagnation and despair. ${ }^{70}$

68. This statement is equivalent to the normal historical statements that authority was becoming centralized, that loyalty was beginning to move from local (or lordly) affairs to the king's government.

69. Palmer, 'Feudal Framework', supra note 36 at 1133.

70. Bolton, English Economy, 73. 


\section{Magna Carta, 61}

Profound legal and economic changes necessarily suppose a certain change in cultural expectations. That cultural change was embodied in Magna Carta. Magna Carta in some sense was the consequence of a multiplicity of problems that made King John vulnerable to baronial rebellion. In a deeper sense, however, Magna Carta resulted from a change in attitude about the proper role of discretion in lordship: about the nature of justice. John suffered from a lack of magnanimity and an excess of distrust, ${ }^{71}$ from severe military losses, ${ }^{72}$ and from his dispute with the papacy over the appointment of a new archbishop of Canterbury. ${ }^{73}$ But John was not radically more high-handed than his brother or father. ${ }^{74}$ Indeed, part of his problem derived from the fact that he devoted more attention to English government after the loss of Normandy and Anjou. ${ }^{75}$ Regardless of the personality of the king, however, a reaction to the Angevin style of exercising monarchical power was not surprising. The Angevins had retained a form of kingship that embodied old-style lordly authority, ${ }^{76}$ while the personnel they commanded as king grew into a more uniform bureaucracy more effective and more deeply and uniformly felt. In the reign of Henry II, this had not caused any particular-problems: all lords possessed powers and broad discretion roughly similar to those of the king. Royal powers were little different and thus little resented. ${ }^{77}$ By John's reign, however, the regulation of feudal courts and lordly authority by the king's court had produced a standard of justice that increasingly eliminated discretionary justice, that valued rigid rules of law more highly than

71. W.L. Warren, King John (Berkeley and Los Angeles, 1978), 190-91, 257-59.

72. Ibid. at $96-99,102-105$.

73. Ibid. at 154-73.

74. Ibid. at 174-80; Doris M. Stenton, English Justice Between the Norman Conquest and the Great Charter, 1066-1215 (Philadelphia, 1964), 88-114; J.C. Holt, Magna Carta (Cambridge, 1965), 38.

75. John's attention to the courts together with the discretion acknowledged to reside in the king in person as distinct from his ministers made his presence a worrisome matter, quite apart from his personality. D. Stenton, English Justice, supra note 74 at 93-114.

76. Milsom, Legal Framework, supra note 38 at 25. The perception that the king's prerogative was in large part not something extraordinary but merely a maintenance of old right explains why the royal prerogative did not receive much attention as such until the reign of King John. Bryce Lyon, A Constitutional and Legal History of Medieval England, 2nd. ed. (New York, 1980), 496.

77. In this context, it is particularly interesting to note that one of the precursors of Magna Carta (1215), c. 39 was the protest against disseisins made by the mere will of royal ministers. The resolution in 1191 was that free tenants would be treated by judgment in the king's court 'according to the lawful customs and assizes of the realm or by the mandate of the lord king'. Holt, Magna Carta, supra note 74 at 103. Magna Carta (1215), c. 39 is pointed precisely against royal disseisins by will, previously thought acceptable. 
discretion. The pseudo-feudal content of Magna Carta, c. 61, demonstrates that baronial perception of the changed social-legal world.

The enforcement clause of Magna Carta, chapter 61, established a council of twenty-five barons to secure the peace. It provided that the barons could choose twenty-five of their number who would be particularly responsible for enforcing the provisions of Magna Carta. If the king or any of his officers violated the charter, the offense would be reported to a committee of four barons. They would then petition the king for redress. After forty days ${ }^{78}$ without satisfaction, the twenty-five barons and the whole community of the realm could distrain the king by seizing his castles, lands, and possessions until satisfaction was made, whereupon everything would be restored. Moreover, the king undertook to assist in having people take an oath to obey the orders of the twenty-five. This court of twenty-five was neither a nostalgic reincarnation of old-style feudal courts nor a precocious anticipation of parliament. ${ }^{79}$ It was rather a precise reflection of the feudal courts and the feudal concerns of England in 1215.

Feudal concerns permeated Magna Carta. A major portion of the 1215 version sought to define various aspects of the feudal relationship ${ }^{80} \mathrm{Chap}$ ters 2-8 were quite explicit. They laid out a set relief to be paid by heirs of the king's tenants; forbade the demand of a payment of relief when the heir had already been in wardship; provided for wardship of lands to preserve their value for the heir when he came of age; mandated that heirs would be married without disparagement; gave assurance that widows would receive their marriage portion and inheritance promptly, as well as their dower; ${ }^{81}$

78. Note that the forty-day period was the same as the notice to be given for a meeting of the magnates to render counsel. Magna Carta (1215), c. 14.

79. Sayles regards the clause as a 'legalization of war' and in the end does not distinguish between the intent of the clause itself (first qualified by the correct comment that 'there was no thought of deposing the Lord's annointed') and the effect of the rebellion that followed on the royal intransigence toward distraint ("Magna Carta . . . put down in black and white... that, if he abused his power, he forfeited his authority and position'. G. O. Sayles, The Medieval Foundations of England (New York, 1961), 406-407. Jolliffe imports into the clause the idea of diffidation, so that the clause legitimated feudal rebellion. J.E.A. Jolliffe, The Constitutional History of Medieval England from the English Settlement to 1485, 4th ed. (New York, 1961), 258-59. But the barons were supposed to distrain only, and the clause contains no hint of diffidation. McKechnie relates the clause likewise to diffidation and feudal rebellion and raised further the question of sovereignty: "If it had been possible to put so violent an expedient into practice, the "sovereignty", or supreme power in England, would have been split in two. John would have held the sceptre only until his opponents declared that he had broken the Charter, when, by his own previously-granted mandate, it would pass to the twenty-five barons.' William S. McKechnie, Magna Carta: A Commentary on the Great Charter of King John, 2nd. ed. (New York, 1914), 468. Holt's treatment is more accurate, but does not treat the clause's relationship to the common law. Holt, Magna Carta, supra note 74 at $239-40$.

80. Holt, Magna Carta, supra note 74 at 206-211.

81. See S.F.C. Milsom, 'Inheritance by Women in the Twelfth and Early Thirteenth Centuries', in Morris S. Arnold, Thomas A. Green, et al., On the Laws and Customs of England: Essays in Honor of Samuel E. Thorne (Chapel Hill, 1981). 
and forbade coercion to make widows remarry while preserving the lord's (the king's) right to consent to her marriage if she wanted to marry again. Chapter 12 provided that there would be scutages and aids only in certain situations. The barons and their advisors were deeply concerned with the consequences of their feudal relationship with the king. In large part, moreover, what they were seeking was not new. The king's court had increasingly been making them treat their men as they were now demanding that the king treat them. ${ }^{82}$ They were applying to the king the new common law standards of proper treatment; the king until then had preserved the old, pre-common law style of lordship.

The barons continued to consider their feudal courts important institutions, despite crippling regulation by the king's court. Chapter 34 , for instance, mandated that the writ precipe not be issued in such a manner as to deprive free men of their courts. The problem confronted was the litigant's ability to avoid the feudal court and thus avoid the lord's supervision by purchasing a precipe writ without justifying his choice of venue. If one excludes the mere uncontrolled and/or positively Machiavellian issuance of precipe writs as improbable, the problem presented in the precipe writs could well have originated with the issuance of royal protections to individuals granting them the privilege of not being impleaded elsewhere than before the king or his justices. Such a protection possessed by the tenant would legitimate the plaintiff's purchase of a precipe, but could well have left the lord in ignorance of the possible impending change in tenants: an inappropriate situation in 1215 and still for some further decades. Chapter 34 mandated that the lord not be circumvented in such fashion. The immediate result was the disappearance of the undifferentiated precipe $e^{83}$ and its replacement by two forms of precipe writs containing jurisdictional clauses. ${ }^{84}$ Those clauses explained either that the claimant claimed to hold directly of the king or that the proper lord had remitted his jurisdiction in this individual case to the king. ${ }^{85}$ Cases involving such privileged individuals would thus have had to originate in the feudal courts and then be removed, or else the claimant would have to obtain the lord's consent originally to have the case come in the king's court. The feudal court could not simply be ignored.

Chapter 39 (in later issues of Magna Carta to become the famous chapter 29) demonstrates a similar mindset in regard to feudal courts. The chapter

82. Milsom, Legal Framework, supra note 38 at 25; Palmer, 'Feudal Framework', supra note 55 at 1163 .

83. Glanvill, I.6; Robert C. Palmer, The County Courts of Medieval England, 1150-1350 (Princeton, 1982), 165.

84. Early Registers of Writs, Elsa de Haas and G.D.G. Hall, eds. Selden Society, vol. 97 (London, 1970), 36-37 (CC. 8, 10). I am inclined to reject the suggestions that Magna Carta, c. 34, precipitated the inclusion of entry words as jurisdictional clauses, because I cannot see any major change in writs of entry immediately after Magna Carta. Palmer, 'Origins of Property', 39.

85. Milsom, Historical Foundations, supra note 48 at 125-26. 
forbade punitive royal action against individuals unless 'by the lawful judgment of his peers or by the law of the land' ${ }^{86}$ The undesirable royal actions fell mostly under the category of crown pleas, since arrests, imprisonment, outlawry, exile, and general destruction of an individual were mentioned. Perhaps the best summary would be those actions a lord would take against one he considered disloyal or hostile, and thus guilty of feudal treason, in this case, of course, against the king. But disseisins were also mentioned, so that one must assume that the difficulties were not completely restricted to crown pleas. The relevant problem with chapter 39 is the meaning of 'lawful judgment of his peers'. The meaning that was later read into that phrase was trial by jury. In that reading, the vel in 'by the lawful judgment of his peers or by the law of the land' takes a conjunctive, instead of disjunctive meaning. ${ }^{87}$ Thus 'lawful judgment of his peers' would be merely an anticipatory specification of one crucially important part of the law of the land. But among crown pleas, only de odio et atya made use of the jury. The vast majority of crown pleas were still determined either by battle or ordeal. Jury trial in crown pleas only became regularized as the result of the decrees of the Fourth Lateran Council, which did not reach England until after Magna Carta ${ }^{88}$ Even then, the jury was not the obvious and immediate substitute for the ordeal. Moreover, the use of the jury trial in normal civil matters, such as the assize of novel disseisin, was already so well established that it is unlikely that the barons would have bothered to insist other than that the king proceed by the law of the land, had 'lawful judgment of his peers' really meant trial by jury. The meaning of the phrase, rather, must refer to a feudal court, where a man would really receive judgment, instead of merely a verdict, at the hands of his peers. The court contemplated as rendering such a judgment was the king's feudal court, whether for England or for Wales. That court was not a common law court; it would not proceed by jury trial. The meaning of vel in chapter 39 was thus properly disjunctive, because the feudal court was a proper alternative to proceeding by the law of the land.

Chapter 52 confirms both the meaning of the Chapter 39 'lawful judgment of his peers' and the barons' concern with feudal courts. It falls in the latter part of Magna Carta that details redress of specific problems, here, with problems deriving from disseisins made without lawful judgment of the disseisee's peers. That wording is important, because it avoids the routine words of the assize of novel disseisin: 'unjustly and without a judgment'. The words thus mirror the words of chapter 39 and refer to disseisins made without the judgment of the king's feudal court. The chapter differentiates between wrongful disseisins thus done by King John (personal wrongs and thus properly redressed immediately or submitted to the court set up by chapter 61) and disseisins done by Henry II and Richard (to which John thus had some hereditary claim and could properly claim the crusader's respite

86. See Holt, Magna Carta, supra note 74 at 226-29.

87. McKechnie, Magna Carta, supra note 79 at 381.

88. Milsom, Historical Foundations, supra note 48 at 410-11. 
before holding full justice to the claimants). This chapter showed no disapproval of operating outside the common law courts, only disapproval of operating outside the context of courts, whether feudal or common law. Clearly the people who drafted Magna Carta ${ }^{89}$ did not consider feudal courts either obsolete or irrelevant.

These feudal elements permeating Magna Carta legitimate a closer look at the concerns of chapter 61 and the nature of the council of twenty-five it established. The council was empowered to distrain, not to make war. Distraint, however, was a traditional element of court process; a feudal court distrained a tenant to come to court to answer. ${ }^{90}$ In that situation likewise, satisfaction of the court resulted in return of the distraints. The council was a court. The projected nature of this court is striking for its distance from the feudal obligations described by Glanvill only twenty-seven years earlier. ${ }^{91}$ Such action against a lord then would have resulted in immediate forfeiture; now lords could think of disciplining their own lord without suffering drastic consequences. Then any discipline exercised by a feudal court could well occasion forfeiture; now distraint was merely pressure to be applied with no threat of complete disinheritance. Nevertheless, the king still found being disciplined by his tenants a repulsive idea. Moreover, after John's death, it seemed inappropriate to others: chapter 61 did not survive in the successive revisions of Magna Carta.

The council of twenty-five, however, was in no sense superior to the king. ${ }^{92}$ Simply because they were empowered to distrain and to enforce their lord's undertakings against him would not have been equivalent in their minds to being superior to their lord. They were admittedly in a desperate position; their desires were to put the king under restrictions similar to those under which the king's court put them. Those restrictions had increasingly come to seem the proper standards for just action. But there was no superior court to bind the king. The only alternative was to create the same effect within the feudal court. Feudal courts, by their very nature, were capable of

89. Holt casts doubt on the decisive influence of Stephen Langton in the drafting of the charter, and proposes instead the influence of judges, officials, and clerks. Holt, Magna Carta, supra note 74 at 175-200. The problem with that suggestion is that they were John's appointees. More likely drafters would be the baron's seneschals, who were both lawyers and administrators. They had both the sense of technicality and the responsiveness to baronial desires, as well as a wider perspective concerning the 'free tenant'. See R.C. Palmer, 'Origins of the Legal Profession in England', 11 Irish Jurist 126-46 (1976); Palmer, County Courts, supra note 83 at 113-38.

90. Milsom, Legal Framework, supra note 38 at 10-11.

91. Superiority or inferiority cannot be determined by the locus of the power to render judgments. Medieval courts often had the tenants rendering judgments, both early on in the king's court and routinely in county and feudal courts. The power to render judgments only establishes a group as superior if that corresponds also with social perceptions and politics. The barons, however, could well have perceived themselves as merely rendering judgments on the lord of the court, without denying (or concluding anything concerning) his superiority.

92. Milsom, Legal Framework, supra note 38 at 10. 
rendering judgments contrary to their lord's desire: that was the preservation of the group interest and the sociological reason why the homage group and not the lord rendered judgments in a feudal court. What Magna Carta added to this royal feudal court was the power to distrain its lord. Distraint of the lord was as close as they could come to simulating the king's court's regulation of their own feudal courts. Inferiors here acted on their superior, trying to make him abide by new standards of justice.

The execution of the project was impractical, particularly with an Angevin king. The attempt was nonetheless worthwhile: it established a new set of guidelines and expectations. ${ }^{93}$ For understanding the barons and the nature of the change in the law, however, chapter 61 is most important. It demonstrates that to some small extent they realized what had happened and were capable of trying to match the effects that the common law had had on them now in their own dealings with the king. As Milsom has said about Magna Carta, 'the myth should be allowed to stand, but on its head'. ${ }^{94}$ The Angevin kings had themselves established the rules by which the magnates now wanted even monarchs to abide. Those rules had given a new element to the conception of justice, an element hostile to discretion and partial to rigid rules.

\section{Conclusion}

The appearance of property was not a 'mere legal' phenomenon, without impact on society. The establishment of property rights in land carried with it a diminution, although hardly a disappearance, of the dependence of tenants on their lords. The obverse side of that increased independence was a greater acceptance and reliance on the royal institutions that now protected, even guaranteed those resources so vital to the current needs of individuals and the projected needs of their survivors. That crucial role of beneficial care had been assumed now by the king's government. The social impact of the change that actually happened, however, can be quantified by examining other effects of the origins of the property. The regulation that secured tenants from lordly supervision and so produced property, produced by the same token greater liquidity of the major economic resources of that society: the land. The result of that change, coupled with the easy availability of silver, produced one of the two monumental pre-modern English inflations, despite the presence of other severe deflationary pressures.

The regulation that produced the common law also changed ideas about justice. To the extent that feudal courts had dealt with matters not strictly determined by procedure, they had operated in a discretionary framework.

93. Magna Carta was not a statute, but a grant. Such a royal grant was not subject to interpretation as strict rules of law by the court against the king: Magna Carta, like coronation charters, was a serious undertaking, taken seriously by all, but not rigid. This became even more so after c.61 was deleted from the document.

94. Milsom, Legal Framework, supra note 38 at 25. 
That framework had operated by custom, a complicated mix of what had been done before and what, all appropriate considerations weighed and balanced, ought now to be done. Acceptance of custom as the standard of regulation, wielded by bureaucratic minded justices, resulted in rigid rules of law, applied perhaps normally in ways entirely congruent with old applications, but now also in situations that were entirely inappropriate. The rigidity of those substantive rules, a new phenomenon in England, came to seem the just way to proceed. A model of law that venerated inflexible rules began to supersede the old discretionary model. The degree to which the model had been accepted appears in Magna Carta. That change in expectations made the Angevin continuance of old-style lordly prerogativesparticularly when bureaucratic agencies came to reinforce royal authorityseem unjust. In the particular circumstances of John's reign, then, the barons felt justified and capable of trying to regulate the lord king in his court as he had been regulating them in theirs. By 1215 the common law was well on its way to becoming a legal system; it had likewise become an indispensable part of the way in which Englishmen thought and the way in which they perceived themselves. 